Вісник Житомирсъкого державного иніверситети імені Івана Франка. Педагогічні науки. Bun. 4 (103)

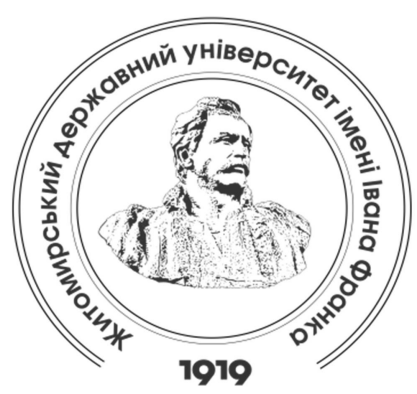

Zhytomyr Ivan Franko State University Journal. Pedagogical Sciences. Vol. 4 (103)

Вісник Житомирського державного університету імені Івана Франка. Педагогічні науки. Вип. 4 (103)

ISSN (Print): 2663-6387

ISSN (Online): 2664-0155

UDC 378.147:37.091.313

DOI 10.35433/pedagogy.4(103).2020.43-50

\title{
ORGANIZATIONAL AND METHODOLOGICAL ASPECTS OF CONTEXT SELF- ORGANIZATION TRAINING OF FUTURE TEACHERS IN PROFESSIONAL ACTIVITY
}

\section{N. M. Myronchuk*, S. L. Yatcenko**}

The urgency of the topic is provoked by innovative processes in the system of higher education, including increasing requirements for the professional activity of HEI teachers. The educators play a major role in the system of modernization of higher education. Thus, there is a need to improve the theoretical and methodological foundations of teachers 'training in higher education institutions. The need to perform professional activities in rapidly changing and nonstandard conditions raises the self-organization competence forming of a higher education teacher in professional activities.

The survey results of teachers-practitioners and undergraduates on self-organization in professional activity are presented. The generalized indicators of formation of levels of selforganization competence in experimental and control groups are shown in professional activity. The difficulties of self-organization in educational work are identified, namely: insufficient development of activity planning skills; improper level of self-reflection processes, self-regulation activity; the problem of rational distribution of internal and external resources; the presence of organizational difficulties in non-standard life situations.

The following components of the methodical system of future higher education teachers contextual training in self-organization during professional activity are determined: theoretical and methodical basis (educational professional program, educational and working programs, syllabi of educational disciplines, instructive-methodical materials, manuals, cases), organizational pedagogical tools, forms, methods), methods of implementation (subject-reflexive and context-design strategies). The organizational and pedagogical principles, principles and algorithm of contextual preparation of future higher education teachers to self-organization in professional activity.

Key words: higher education teacher, self-organization competence, context training, methodical system, methods of formation, organizational pedagogical tools, design.

\footnotetext{
${ }^{*}$ Candidate of Pedagogical Sciences (PhD in Pedagogy), Docent

(Zhytomyr Ivan Franko State University)

mironchuknm@gmail.com

ORCID: 0000-0002 1360-6381

${ }^{* *}$ Candidate of Pedagogical Sciences (PhD in Pedagogy), Docent

(Zhytomyr Ivan Franko State University)

sl.yatsenko.gdu@gmail.com
}

ORCID: 0000-0002-2532-7312 


\title{
ОРГАНІЗАЦІЙНО-МЕТОДИЧНІ АСПЕКТИ КОНТЕКСТНОЇ ПІДГОТОВКИ МАЙБУТНІХ ВИКААДАЧІВ ДО САМООРГАНІЗАЦІї У ПРОФЕСІЙНІЙ ДІЯАЬНОСТІ
}

\author{
Н. М. Мирончук, С. М. Яценко
}

Актуальність теми зумовлена інноваиійними проиесами у системі вишої освіти, посиленням у иьому зв'язку вимог до професійної діяльності викладача вишої иколи. Викладач виконуе головну роль у системі модернізаиій вищої школи, тому існує потреба удосконалення теоретичних та методичних основ його підготовки у закладі вищої освіти. Необхідність виконувати професійну діяльність у швидко змінюваних та нестандартних умовах актуалізуе питання формування у викладача вишоі иколи компетентності самоорганізаиї у професійній діяльності.

Представлено результати опитування викладачів-практиків $i$ магістрантіввипускників шодо проблем самоорганізаиї професійної діяльності. Подано узагальнені показники діагностичного вивчення рівнів сформованості компетентності самоорганізаиіі майбутніх викладачів вищої школи у професійній діяльності в експериментальній та контрольній групах. Виявлено трудноиі самоорганізаиї навчальної праиі майбутніх викладачів: недостатня розвиненість умінь планування діяльності; неналежний рівень проиесів саморефлексії, саморегулювання діяльності; проблема раиіонального розподілу внутрішніх $і$ зовнішніх ресурсів; наявність організаиійних трудноиів у нестандартних cuтуаиіях життедіяльності.

Визначено складники методичної системи контекстної підготовки майбутніх викладачів вищої школи до самоорганізаиї̈ у професійній діяльності: теоретичнометодичне підтрунтя (освітньо-професійна програма, навчальні й робочі програми, силабуси навчальних дисииплін, інструктивно-методичні матеріали, посібники, кейси), організаиійно-педагогічні інструменти (форми, методи), методика реалізаиії (суб'єктнорефрлексивна та контекстно-проєктувальна стратегіi). Розкрито організаиійнопедагогічні засади, приниипи та алгоритм контекстної підготовки майбутніх викладачів вищої школи до самоорганізаиї у професійній діяльності.

Ключові слова: викладач вищої школи, компетентність самоорганізаиї, контекстна підготовка, методична система, методика формування, організаційно-педагогічні інструменти, проєктування.

\begin{abstract}
Introduction of the issue. Innovative processes in the higher education system, increasing requirements for higher education teacher (HET) professional activity, create objective preconditions for theoretical and methodological substantiation of approaches to contextual training of future HET from the side of a state, society, employers and learners. Therefore, its content needs alteration and structural renewal, as well as self-organization compentence requires inclusion in the educational results of professional training.
\end{abstract}

Current state of the issue. Systematic study of scientific resources on a HETs training for professional pedagogical activity revealed that the researches of O. Antonova, S. Vitvytska, V. Kaplinsky, V. Kravchenko,
A. Kuzminsky,
L. Lebedyk,

N. Machynska,

O. Plakhotnik,

G. Romanova and others are dedicated to the issue under study. The development of contextual and competence training is reviewed by A. Verbytsky, O. Shapran, N. Pobirchenko, N. Demyanenko, V. Kovalchuk, V. Strelnikov, V. Yagupov. Also, research included the self-organization phenomenon in pedagogy, which is investigated and developed by O. Gura, O. Demchenko, N. Dudnik, A. Kylivnyk, T. Prykhodko, etc.

The outline of unresolved issues brought up in the article. At the same time, despite the significant number of 
studies, the issues of developing a methodological system of contextual training of future higher education teachers to self-organization in professional activities are not sufficiently covered.

Aim of research is to present the results of a survey of higher education teachers in order to identify problems related to self-organized work; show the results of studying the self-organization formation among undergraduates, who acquire the qualification of a teacher, the self-organization skills and identify the algorithm for designing a methodological system in order to increase the level of their selforganization in educational / professional activities.

Results and discussion. The ascertaining stage of the experiment involved conducting a survey of teachers-practitioners and graduate students in order to identify problems related to self-organization in professional / educational activities.

The study involved 117 teachers and 148 undergraduates from Vinnytsia, Zhytomyr, Zaporizhia, Kyiv, Rivne, Sumy regions. The method of selfassessment of self-organization level was used on four main indicators, mainly: "insufficient" (low), "situational" (medium), "mostly available" (sufficient), "always available" (high).

Table 1 shows the obtained indicators at low and medium levels, which, as we can see, highlights a critical attitude of respondents to their own skills and confirms the existence of certain difficulties associated with the self-organization of educational or professional activities.

Difficulties of Self-Organization of Educational/Professional Activity

Table 1

\begin{tabular}{|c|c|c|}
\hline \multirow[t]{2}{*}{ Self-Organized Work Characteristics } & \multicolumn{2}{|c|}{$\begin{array}{c}\text { Indicators of Low and } \\
\text { Medium Formation Levels, } \\
\%\end{array}$} \\
\hline & $\begin{array}{l}\text { Teachers } \\
(117)\end{array}$ & $\begin{array}{l}\text { Graduates } \\
(148)\end{array}$ \\
\hline Defining the goals of pedagogical activity & 35,0 & 40,5 \\
\hline Planning of educational / professional activity & 36,4 & 33,8 \\
\hline Analysis of educational / professional activities & 33,5 & 48,6 \\
\hline $\begin{array}{l}\text { Self-control of actions, states, emotions in situations of } \\
\text { interaction }\end{array}$ & 29,5 & 39,2 \\
\hline Self-control in stressful situations & 40,2 & 48,6 \\
\hline Rational distribution of working time & 41,2 & 37,8 \\
\hline $\begin{array}{l}\text { Operational selection and implementation of optimal } \\
\text { ways to perform educational / professional tasks }\end{array}$ & 32,5 & 45,9 \\
\hline Workplace organization & 39,0 & 31,1 \\
\hline Timeliness of professional tasks & 32,4 & 40,5 \\
\hline Delegation of tasks / assignments & 49,4 & 75,7 \\
\hline $\begin{array}{l}\text { Ability to apply exercises, psychotechnics, techniques } \\
\text { to restore physical and emotional state and efficiency }\end{array}$ & 44,1 & 70,3 \\
\hline
\end{tabular}

Another task of the ascertaining stage was to determine the initial level of formation of undergraduates majoring in 011 "Educational, Pedagogical Sciences" ("Higher School Pedagogy") (226 people) self- organization competence in professional activities at the beginning of training.

In Table 2 we presented the generalized indicators of diagnostic study of self-organization competence formation levels in professional activity on certain structural components 
(motivational, cognitive, practical, components).

volitional, reflexive-evaluation

Table 2

Generalized Indicators of Self-Organization Competence Formation Levels of Future Higher Education Teachers in Professional Activity at the Ascertaining Stage of Experiment

\begin{tabular}{|l|c|c|c|c|}
\hline \multirow{2}{*}{\multicolumn{1}{c|}{ Formation Levels }} & \multicolumn{3}{c|}{ Before Experiment } \\
\cline { 2 - 5 } & \multicolumn{2}{c|}{$\begin{array}{c}\text { Experimental } \\
\text { Group }\end{array}$} & \multicolumn{2}{c|}{ Control Group } \\
\cline { 2 - 5 } & Abs. & $\%$ & Abs. & $\%$ \\
\hline Adaptive-Modeling (Initial) & 17 & 14,0 & 18 & 14,4 \\
\hline Structure-Modeling (Average) & 45 & 37,2 & 46 & 36,8 \\
\hline System-Modeling (Sufficient) & 41 & 33,9 & 42 & 33,6 \\
\hline System-Creative (High) & 18 & 14,9 & 19 & 15,2 \\
\hline Total & 121 & 100 & 125 & 100 \\
\hline
\end{tabular}

The results give grounds to assert the awareness of teachers and undergraduates of the importance and necessity of self-organization skills in professional activities, as well as to state the underdevelopment of undergraduate skills of activity planning, rational allocation of internal (personal) and external resources, selfresources, self-development, the presence of organizational difficulties in non-standard life situations.

Solving the problem of contextual training in self-organization of future higher education teachers in the dynamic conditions of professional activity requires justification and development of a methodological system of such training.

Among scientists there is no consensus on the content elements of the methodological system. Thus, the methodological system is defined as a set of hierarchically related components: learning goals, content, methods, tools and forms of learning process organization, forming a single integrated functional structure focused on achieving learning goals (A. Stryuk, etc.) [4]; as a holistic model of pedagogical activity, which is then specified in the project of this activity; normative reflection of a certain area of pedagogical reality (V. Kraevsky, V. Berezhnova) [3]; O. Ilyenko [2] components of the scientific and methodological system of professional training of the future competitive specialist determines: the purpose, tasks, stages.

V. Bykov [1] notes that methodological systems should ensure the implementation of modern teaching methods, provide the possibility of training taking into account the previous experience of learners. The scientist defines the methodological system as an integrated set of teaching methods, thus he identifies the teaching method as a model of the learning process within one learning element, which reflects the orderliness of relations, learning content, participants in the learning process and learning environment.

The methodological system of contextual training of future higher education teachers for self-organization in professional activities is considered as a complex dynamic education of the system type. Its interrelated elements (content (educational, qualification and professional program, curricula), forms, methods, means) provide training for future HETs in self-organization during professional activities. In this way the formation of such an integrative quality as the self-organization competence is supported. The functioning of the methodological system is correlated 
Вісник Житомирсъкого державного иніверситети імені Івана Франка.

Педагогічні науки. Bun. 4 (103)

with the internal structure of the system itself, and the change of one or more of its components will change the whole system.

The methodical system contains the following structures: theoretical and methodical basis, which represents methodical maintenance of undergraduates training (educational programs, qualification programs, syllabi of disciplines, instructive- methodical materials, manuals). cases (professionally-oriented situations of self-organization), organizational pedagogical tools (forms, methods), methods of realization of methodical system, which is represented by subject-reflexive and context-design strategy. It is offered for the following stages:

organizational, cognitive-oriented, development (fig. 1).

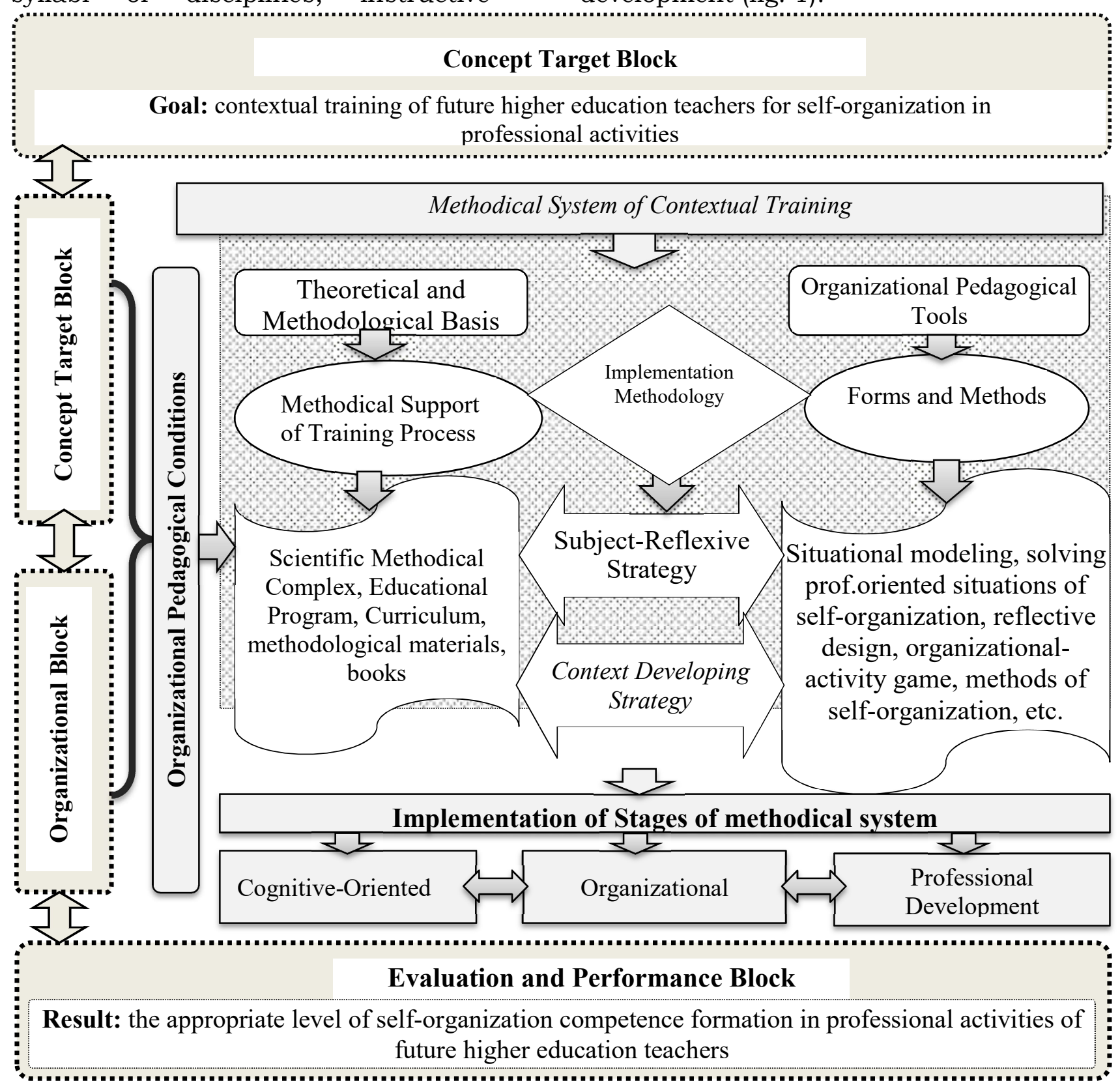

Fig. 1. Methodical system of contextual self-organization training of future higher education teachers in professional activity 
Following V. Bykov, we consider the design of the methodical system as a systemic process that involves the development of educational specifications. They are based on the theory of learning and ensure the creation of quality teaching materials; study of educational needs, personal characteristics and goals of the learning process, as well as the development of pedagogical systems in accordance with such needs and goals. This process meets the objectives and content requirements of the subject or part of it. It involves the creation of teaching materials, tools for assessing academic achievements and effectiveness of learning activities to form selforganization competence among undergraduates and management of their positive development.

Organizational and pedagogical principles of designing the content, forms and methods of contextual selforganization training in professional activities are defined as the basis for building a holistic pedagogical process on a contextual basis to successfully form general and professional competencies. self-organization competence of higher education teachers.

Designing in the context of research aim implementation is considered as process of scientifically-theoretical and practically grounded establishment of a variant of the forecasted and planned development of contextual selforganization training in professional activity and modeling of actions for its realization.

Organizational and pedagogical principles of this process include analytical forecasting (prognostic) and projective organizational actions:

$\begin{array}{lll}- & \text { analysis of international } \\ \text { (UNESCO Communiqué and }\end{array}$
Recommendations, TUNING project, World Bank study "Professional Skills for Modern Ukraine", etc.) and state requirements for higher education teacher, study of the regulatory framework for training specialists of the second (master's) level of higher education (Law of Ukraine "On Higher Education", National Qualifications Framework) and determining the place of self-organization competence of in their content;

the content formation of contextual training on the basis of the self-organization principle;

development of educational and methodological support for the content of contextual training for selforganization in professional activities by creating educational and methodological complexes of all educational modules and reflect in their content the self-organization competence or its content elements;

- selection and development of forms, methods, techniques, tools of pedagogical guidance and the creation of contextual and professional environment that provide a successful solution to the professional and pedagogical task of forming the selforganization competence in future higher education teachers (fig. 2).

The logic of designing the content and methodological foundations of selforganization training in professional activities is to reproduce the following processes:

1) the study of stakeholder requests and the needs of the region to develop program competencies and learning outcomes and reflect in their content the self-organization competence based on the analysis and consideration of state requirements for training at the second level of higher education (integrated competence);

2) creation of an educational and professional training program for masters (development of the program profile, curriculum, study modules, teaching methods, teaching and assessment) taking into account different types of resources / requests;

3) definition of approaches to teaching and substantiation of contextual and content bases of self- 
organization training in professional activity and designing of formation content of self-organization competence on the basis of certain approaches;

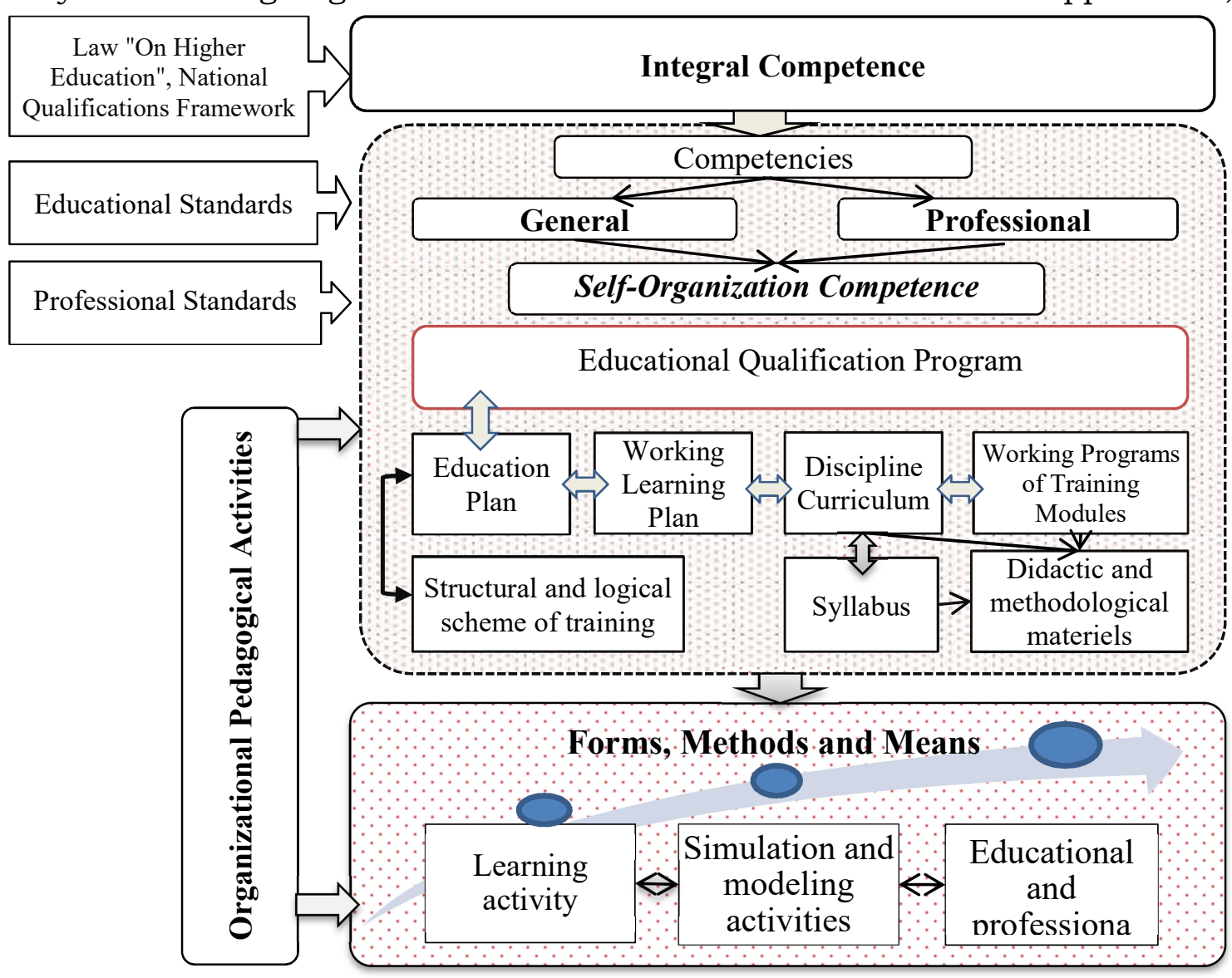

Fig. 2. Organizational and pedagogical principles of designing the content, forms and methods of contextual self-organization training in professional activities of future higher education teachers

4) development of organizational and methodological support for the process of self-organization training in professional activities, educational and methodological complex of the discipline "Fundamentals of SelfOrganization in Professional Activities" for future higher education teachers.

Design in our researches is carried out taking into account the principles as a system of requirements for the content, forms and methods of professional self-organization training of future higher education teachers in professional activities. Based on the theoretical analysis and the results of our own research, we have identified the principles of selection of content, forms and methods of contextual selforganization training of undergraduates in professional activities:

- compliance of the content of education with the requirements of the development of society, science and culture, the demands of the labor market, personal needs and individual characteristics of the individual;

- science, which has an essential expression in accordance with the content of training at the level of development of modern pedagogical science; in the formation of a modern scientific picture of the world and the ideas of undergraduates about the general methods of cognition, the 
process of cognition and its mechanisms;

synergetic principles of openness and non-linearity, which provide for updating the content of education through the receipt of new educational information and multivariate / alternative ways of professional and pedagogical development of future higher education teachers;

- variability of content and multilevel, which provides an opportunity for undergraduates to develop an individual educational trajectory;

- contextual-professional

orientation and problematic content of education;

- unity of theoretical and practical components of training, modeling of situations of self-organization in educational and professional activity;

- structural unity of the components of education content, their relationship at different levels of design.

Conclusions and research perspectives. Design of content, forms and methods of contextual selforganization training of future high education teachers in professional activities involves qualitative and analytical procedures for developing substantive and methodological framework (analysis of social order, labor market demands, regulations, personal needs of potential applicants etc. and development on their basis of learning outcomes and educational content). Their reflection in information and sign models are educational and qualification programs, curricula, syllabi of training courses, training and work programs, internship programs, manuals, teaching materials, etc.

The methodical system of contextual self-organization training of future higher education teachers in professional activity includes the presence of designed content elements (competencies, educational program, curriculum, training programs in specific disciplines, practices, teaching and methodological support, etc.) and appropriate content and optimal forms and methods of training.

Perspectives for further research are to reveal the method of forming the selforganization competence of future teachers of higher education by means of contextually oriented forms and methods.

\section{REFERENCES (TRANSLATED \& TRANSLITERATED)}

1. Bykov, V.Iu. Metodychni systemy suchasnykh informatsiino-osvitnikh tekhnolohii [Methodical Systems of Modern Information and Educational Technologies]. Retrieved from: https://core.ac.uk/download/pdf/110 83983.pdf [in Ukrainian].

2. Ilienko, O.L.

(2016).

Pedahohichni komponenty naukovometodychnoi systemy profesiinoi pidhotovky maibutnoho konkurentospromozhnoho fakhivtsia [Pedagogical Components of the Scientific and Methodological System of Professional Training of the Future Competitive Specialist]. Pedahohika ta psykholohiia - Pedagogy and psychology, 55, 155-163 [in Ukrainian].

3. Kraevskyi, V.V., Berezhnova, E.V. (2006). Metodolohiia pedahohiki: novyi etap [Methodology of Pedagogy: a New Stage]: ucheb. posob. Moskva: "Akademiia", 96-97 [in Russian].

4. Striuk, A.M., Striuk, M.I., \& Koval, M. V. (2013). Metodychna systema navchannia informatychnykh dystsyplin $z \quad$ vykorystanniam khmarnykh tekhnolohii, [Methodical System of Teaching Computer Science Disciplines Using Cloud Technologies]. Retrieved from http://lib.iitta.gov.ua/1193/1/stryuk v3.pdf [in Ukrainian].

Received: November 04, 2020 Accepted: December 08, 2020 